\title{
Preface: Impact of human activities on biodiversity of large rivers
}

\author{
Helmut Habersack • Daniel Haspel • \\ Susanne Muhar $\cdot$ Herwig Waidbacher
}

Published online: 4 March 2014

(C) Springer International Publishing Switzerland 2014

The pressures and impacts on the World's Large Rivers have increased greatly in recent years, as a consequence of their exploitation to meet various human needs. Large rivers are particularly exposed to problems of multiple uses, often with conflicting aims. At the global scale, river systems are altered by increased nutrient loads leading to eutrophication of river stretches, navigation and hydropower plants deteriorating ecosystem functions and further human uses leading to far reaching problems further downstream. These challenges point also to the need for more integrated management approaches and consideration

Guest editors: H. Habersack, D. Haspel, S. Muhar \&

H. Waidbacher / Impact of human activities on biodiversity of large rivers

\section{H. Habersack · D. Haspel}

Institute for Water Management, Hydrology and Hydraulic Engineering (IWHW), University of Natural

Resources and Life Sciences (Boku), Muthgasse 107,

1190 Vienna, Austria

H. Habersack · D. Haspel ( $\square)$

Christian Doppler Laboratory for Advanced Methods in River Monitoring, Modelling and Engineering, University of Natural Resources and Life Sciences (Boku), Vienna, Austria

e-mail: daniel.haspel@boku.ac.at

S. Muhar $\cdot$ H. Waidbacher

Institute of Hydrobiology and Aquatic Ecosystem

Management (IHG), University of Natural Resources and Life Sciences (Boku), Max-Emanuel-Straße 17, 1180

Vienna, Austria of catchment and river interactions emphasizing land use management and effects of these uses.

At the global scale, there is currently no overview assessment of the current status of the world's large rivers, the conflicting demands on such rivers, and likely future anthropogenic impacts, as well as the potential for restoration, improvements in integrated management and the associated problems caused by their multiple uses. The International Conference on 'The Status and Future of the World's Large Rivers' and this Special Issue in Hydrobiologia on 'Impact of human activities on biodiversity of large rivers' aim to provide a global forum for a wide-ranging discussion of key issues related to research on large rivers and to their effective and sustainable management, involving both scientists and decision makers. The sequence of papers in the special issue highlights the current situation in different river systems with regard to river conservation and rehabilitation, and human impacts on flora and fauna. Beside seven other Special Issues in SCI journals, this Special Issue is an outcome of the 1st International Conference on the Status and Future of the World's Large Rivers held in April 2011 in Vienna (http:// worldslargerivers.boku.ac.at/wlr/). The 2nd conference will take place in Manaus, Brazil, in July 2014.

\section{References}

Habersack, H. \& T. Hein, 2013. International conference on the status and future of the world's large rivers April 11-14, 2011 Vienna. Austria. River Systems 20(3-4). 
Habersack, H., D. Haspel \& I. Campbell, 2013. Integrated management of large river systems. International Journal of River Basin Management 11(2): 137-236.

Habersack, H., D. Haspel \& B. Schober, 2013. Morphological characterisation and fluvial processes of large rivers at different time scales. Geomorphology. doi:10.1016/j.geomorph. 2013.11.003

Habersack, H. \& D. Haspel, 2013. Sediment loads and processes in large rivers. International Journal of Sediment Research 28(4): 470-485.
Habersack, H., D. Walling \& D. Haspel, 2013. The hydrology of large rivers. Hydrological Processes 27(15): 2103-2104.

Habersack, H., D. Haspel \& M. Kondolf. Climatic, hydrological and land use impacts on large rivers. Water Resources Research (in press).

Habersack, H., D. Haspel \& T. Glade. Flood prevention and mitigation at large rivers. Natural Hazards (in press). 